\title{
The Uneven Integration of Polish Manufacturing Industries into the European Single Market
}

\author{
Anna Wziątek-Kubiak \\ Institute of Economics
}

\begin{abstract}
The paper aims to show the uneven process of integration of Polish manufacturing into the Single Market due to differentiational changes in competitiveness across industries (third digit level of NACE Rev. 1.1 classification) in 1996-2001. It starts with a discussion on the nature and measurement of competitiveness. Since this notion is derived from that of competition as rivalry, the effects and factors of competition are the focus. Section 2 describes the overall picture of changes in competitiveness of Polish manufacturing measured by changes in market shares and relative labour productivity. Changes in relative unit export values as a measure of changes in quality of products produced in Poland are considered. Section 3 analyses the usefulness of various measures of changes in the competitiveness of Polish manufacturing in depicting the uneven process of integration of industries into the Single Market. In the last section the winners and losers in the process of integration of Polish manufacturing into the Single Market and the factors determining uneven integration are analysed.
\end{abstract}

- JEL classification: D24, D40, F14, F15, J24, L10, L60

- Keywords : Competitiveness, Integration, Transition economies, Competition

\footnotetext{
*Corresponding address: Anna Wziątek-Kubiak, Institute of Economics, the Polish Academy of Science. Institute of Economics, Polish Academy of Science. 00-330 Warszawa, ul. Nowy Swiat 72, Phone: +48(22)657-2707, Fax: +48(22)826-7254, E-mail: hkubiak@inepan.waw.pl 


\section{Introduction}

In 1991, Poland signed the European Agreement establishing association with the European Communities and their member countries. This Agreement contributed to tangible changes in the Polish economy, although it is not clear the extent to which these were due to the Agreement itself or to other factors. It did undoubtedly result in an adjustment of Poland's economy to the mechanisms and provisions in force in the European Communities. However, this process was uneven among manufacturing industries. Some of them adjusted quite smoothly and increased competitive pressure on EU producers, while others have been competed out.

The uneven process of integration of Poland's manufacturing industries in 19962001 as an effect of the differentiation in progress made in competitiveness and its factors are central to this paper, which focuses on the bases and measures of such progress in integration. The timeframe, 1996 to 2001, witnessed extensive liberalisation of Polish manufacturing with the EU. By lowering barriers to mutual trade it brought equal market access to all market participants. It also resulted in increased competition and introduced a process of selecting firms operating on both Polish and EU markets. Some were in effect competed out of the enlarged EU market while others expanded and have strengthened their market position.

The paper covers four sections.

Section 1 starts with analysis of the essence of competitiveness as the ability to compete and integrate into the European Single Market. It also deals with the measures of changes in competitiveness that are used to show the uneven progress in integration across industries in Polish manufacturing.

Section 2 covers the overall progress in competitiveness of Polish manufacturing and its main factors.

Section 3 provides a picture of the diversification of Polish manufacturing industries in respect to changes in their ability to compete and integrate into the Single Market.

Section 4 selects and characterises the winners and losers of the integration process.

Conclusions stemming from this analysis wrap up the paper.

\section{A. Competitiveness as the ability to compete, and its measurement}

It is widely acknowledged that progress in competitiveness determines the 
process of real convergence between the new and old member states ${ }^{1}$ as well as their integration (the Copenhagen European Council, June 1993). However, a key problem is that competitiveness as a term has been ascribed with several different meanings and in effect one tends to encounter persistent miscommunication in discussing competitiveness issues. In this paper we deploy the Schumpeterian approach to competitiveness. This approach is in contradiction to another approach based on trade theory which assumes that "all the nations participating in trade benefit from the exchange of the goods thus efficiently produced" 2 and thus neglects "inherent conflicts in international trade" ${ }^{3}$. In trade approach, competitiveness is measured by revealed comparative advantage (RCA), that is by specialization $^{4}$. It was developed in Polish literature ${ }^{5}$ for many years.

In the paper it is presumed that competitiveness derives from competition and thus directly reflects the competition struggle. The term "competition" is used in the sense of rivalry among actual and potential competitors. It is synonymous with terms such as "struggle", "rivalry" and "conflict". Competition is understood with regard to situations in which parties producing substitutes - aiming to achieve the same, but in fact the opposite, goals - end up in conflict. It encompasses the process of some firms pushing others out of the market (and therefore also the goods produced by them). Competition occurs between all market participants producing both non-competitive (price does not cover production costs) and competitive goods, with different levels of competitiveness. It allows only for some competitors to survive. Although non-competitive businesses may also join the competitiveness struggle their products tend, with time, to be eliminated from the market.

This ongoing and never-ending struggle ${ }^{7}$ and the pushing out of the market those goods with lower competitiveness or entirely non-competitive reflects the selection

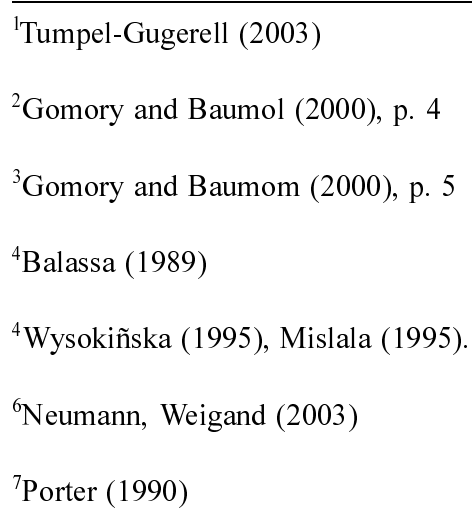


of producers of a given product. Changes in the competitiveness of a given firm's product result in changes in its market position ${ }^{8}$. It is because of this that throughout the literature one often finds 'market share' being treated as synonymous with the performance indicator of competitiveness 9 .

Market participants aim to improve their position on both the domestic and foreign markets on which their goods are sold. Changes in competitiveness of exported products are therefore described by the changes in foreign (export) market share. Changes in competitiveness of domestic-based products competing against imports are described by the changes in domestic market share. Since the range of competition struggle marks the possibilities of verifying competitiveness, the product competitiveness of any given producer (domestic or foreign) is verified on both domestic and foreign markets. It follows that any evaluation of competitiveness of domestic production based solely on exports has limited research capabilities ${ }^{10}$. The need to include changes in both domestic and foreign market shares while analysing changes in competitiveness is more relevant for Poland than for other new member states ${ }^{11}$. Poland is not only much larger than the others but its production is more domestically oriented. Although the share of exports in GDP has increased considerably, most Polish manufacturing is still sold on the domestic market. Our approach to analysing changes in the competitiveness of Polish manufacturing based on changes in both domestic and export market share differs from the commonly used approach, which tends to limit itself to changes in foreign market share.

On the other hand both approaches are not free from some deficiencies. The problem is that measuring changes in competitiveness by changes in market share is distorted by changes in:

- market orientation (domestic or foreign) of production,

- the dynamics of exports and imports compared to production dynamics,

- differences in demand dynamics between domestic and foreign markets,

- changes in product quality.

Changes in both market shares are influenced by changes in orientation of

${ }^{8}$ Frischtak (1999)

${ }^{9}$ Meeksen, Rayp (2000).

${ }^{10}$ Casson (1999)

${ }^{11}$ Wziątek-Kubiak, Lipowski (2000); Glikman and Lipowski (2005) 
production. An increase in domestic market share may be the result of a shift in orientation of production from foreign to domestic. If both markets are open this shift does not reflect changes in competitiveness of production. All the more so given that changes in companies' product share in both markets are also influenced by differences in demand dynamics between them. Rapid domestic demand growth dynamics tend to encourage local producers to develop sales in this market. In such a situation acceleration of growth dynamics of deliveries to the local market may be accompanied by decelerating export growth dynamics, implying stabilisation or even reduction of exports share. This, in turn, results in the fact that a country's production share in world production may increase quicker than its share in international trade ${ }^{12}$.

Changes in a given domestic production's share of the domestic market are the result of changes in size of domestic production compared to exports and imports. A higher rate of growth in foreign trade relative to domestic production tends to result in a fall in the share of domestic production on the domestic market. This change, although it may be the effect of export growth dynamics overtaking growth of production sold on the domestic market, does not necessarily have to mean worsening competitiveness of domestic production. It may be accompanied by a rising share of exports on foreign markets, which would in turn suggest an improvement in competitiveness. Since foreign trade performance and changes in orientation of production influences changes in market share, some additional measures of competitiveness are necessary.

Intuitively, any improvement in the competitiveness of domestic production must take place in a situation of a rising share of domestic products on both domestic and foreign markets. Falling market share on both domestic and foreign markets suggests that the production's competitiveness is worsening. Most ambiguous is evaluating changes in competitiveness of production in cases where changes in domestic and foreign market shares are divergent: for example, when the growth of production share in one market (for example the domestic market) is accompanied by a decrease in the share of another (foreign) market. Deficiencies in using of market share measures to gauge changes in competitiveness oblige one to consider other factors that may impact on the effects of competition.

Deriving the notion of competitiveness from the ability to compete (with rivals) and exploring market share as a measure of changes in competitiveness implies,

${ }^{12}$ Dlugosch and al. (1996) 
firstly, that it is a relative term. Any assessment of the competitiveness of a given product manufactured by a company by measuring its productivity must be related to the productivity of its rivals on the market where competition takes place. Improving productivity alone does not necessarily imply a rise in the company's micro-competitiveness, since another company, foreign or domestic, may increase its production productivity by a wider margin. In such a case, a drop in its international competitiveness level may accompany an improvement in its productivity. This is why when analysing in the paper the factors influencing changes in the competitiveness of Polish manufacturing, relative measures (as compared to the EU average) are used, for example relative labour productivity, relative product quality and investment rate.

Secondly, since competitiveness reflects competition, its boundaries and its focus are the same for all competitors. The focus of competitiveness research is the product market, its sub-sectors and substitutes produced by various companies. In this paper we focus on changes in competitiveness of Polish-based industries as compared to the EU average. Our concern is the effects and factors of competition occurring in Polish and the EU product markets. The relative quality of Polish manufacturing products is also taken into account.

Thirdly, and importantly, methods of competition (price and non-price) are reflected in the methods of changes in competitiveness. For many years great importance is given to improving productivity and differentiating products ${ }^{13}$. However, economists have relatively recently started to include quality of goods and their differentiation as factors influencing firms' and industries' performance. The importance of quality in any analysis of competitiveness is related to competition methods and field of competition. Firms challenge not only those consumers already present on their product market, but also others and their disposable incomes. Firms want them to buy their products instead of goods not even belonging to the same industrial category. Therefore, competition occurs not only within a quality segment of a single branch, but also across them.

The role of quality in competition and competitiveness analysis is significant for the catch-up countries as they experience a rapid change in demand structure towards goods of higher quality and higher price. If the process of catching-up is not accompanied by improvements in quality, but only by improvements in productivity, then even with enhanced competitiveness demand factors will restrain

\footnotetext{
${ }^{13}$ Porter (1990), p. 9, 10, 21, 29
} 
high production growth dynamics. Therefore, in the catch-up process production dynamics will tend to be higher if accompanied by improvements in quality.

The theoretical importance of differentiation of products and its factors in explaining the evolution of foreign trade is based on the recent trade and endogenous growth theories expounded by Grossman and Helpman (1991a, b). Their models incorporate concepts of quality ladders and vertical product differentiation. High-income consumers tend to buy higher quality product variants and the number of variants produced within vertical product differentiation depends on the income spread. Differences in consumers' disposable incomes and changes in them have an impact on the range of competition between producers.

Higher quality makes higher price possible without losing market share. Consequently, in the framework of monopolistic competition, by increasing the quality of goods produced for the domestic market a country can at the same time shift its import demand curve inwards and its export demand curve outwards. It follows that increases in market shares may reflect not only improvements in the relative productivity of the substitute but also an upward shift in the quality ladder. This furthermore allows for entry into a more dynamic segment of the market stimulated by an increase in the disposable income of consumers. This is relevant for analysis of Polish integration into the Single Market. Its high dynamics of GDP growth imply an increase in both productivity and in consumers' disposable income, which could also result in an upward shift in the quality of the products demanded by Polish consumers. Analysis of changes in quality, because it covers the process of adjusting production to changes in demand, shed new light on the process of uneven integration of a given industry into the Single Market.

\section{B. Changes in market position of Polish manufacturing, 1996-2001.}

In the period 1996-2001 ${ }^{14}$ the position of Polish manufacturing in EU25 ${ }^{15}$ intraexports and on the domestic market changed considerably, although remained modest. The growth dynamics of Polish manufacturing exports to the EU-15 were far higher than those of EU25 intra-exports, double the EU15's intra-exports growth and slightly above the growth in the EU's external imports (Table 1). In

${ }^{14}$ Choice of period of analysis was determined by data availability on Polish and the EU manufacturing (on 3 digit level of NACE Rev.1. classification) when paper was prepared. Besides this period covers two sub periods: of high growth rate and of slowdown. Since end of 2001 dynamic of growth of Polish manufacturing started to increase.

${ }^{15} \mathrm{EU}$ members and 10 future new member states 
Table 1. Changes in the shares of Polish exports in the enlarged EU25's intra-exports, in the exports of 10 acceding countries (AC) to the EU and in the external imports of the EU (in per cent)

\begin{tabular}{lccccccc}
\hline & 1995 & 1996 & 1997 & 1998 & 1999 & 2000 & 2001 \\
\hline $\begin{array}{l}\text { Share of Polish exports to EU15 in } \\
\text { enlarged EU25 intra-exports }\end{array}$ & 1.09 & 1.04 & 1.10 & 1.16 & 1.20 & 1.37 & 1.54 \\
\hline $\begin{array}{l}\text { Share of Polish exports to the EU in } \\
\text { the total exports of 10 AC to EU }\end{array}$ & 28.8 & 27.3 & 26.6 & 25.5 & 24.6 & 25.6 & 26.0 \\
$\begin{array}{l}\text { Share of EU15 imports from Poland } \\
\text { in EU15 external imports (a) }\end{array}$ & 2.68 & 2.58 & 2.58 & 2.71 & 2.75 & 2.91 & 3.35 \\
\hline $\begin{array}{l}\text { Share of Polish manufacturing sup- } \\
\text { pliers to the domestic market in 68.6 }\end{array}$ & 65.5 & 62.1 & 60.2 & 58.1 & 58.0 & 57.6 \\
$\begin{array}{l}\text { Polish apparent consumption (b) (c) } \\
\text { Rate of growth of EU15 intra-exports }\end{array}$ & 4.95 & 9.45 & 9.08 & 5.77 & 16.83 & -0.29 \\
\hline \begin{tabular}{l} 
Rate of growth of EU25 intra-exports \\
\hline Rate of growth of Polish exports to EU15
\end{tabular} & 0.80 & 16.72 & 15.61 & 9.75 & 34.34 & 13.17 \\
\hline
\end{tabular}

Data for 91 commodity industries (without 173, 223, 233,272, 273, 275, 284, 285, 333 and 335)

(a) Excluding imports from the new member states,

(b) Data on imports extracted from SAD statistics by CPA classification,

(c) Apparent consumption concerns only enterprises submitting the F-01 form. This means that Polish apparent consumption is underestimated,

Source: Own calculations based on Comext, New Cronos, Destatis and Polish Statistical Office database.

part this was the result of very strong growth dynamics in Polish manufacturing production, also twofold higher (in current prices) than the EU average. However, in 1995-1999 export dynamics of the other 9 New Member States exceeded Polish export dynamics to the EU15. Therefore, although the Polish manufacturing sector was taking a larger part of the European market's upsurge than the EU-15 countries, a considerable chunk of EU15 external imports and EU25 internal exports, it continued to lose out relative to the other new member states.

One feature of the changes in the position of Polish manufacturing in domestic and the EU15 market was its strong differentiation between two sub-periods: in 1996-1998 as compared to 1999 onwards (Table 1). During the period of very high growth in the Polish economy (1996-1998) ${ }^{16}$, the rises in Poland's export shares were markedly smaller, while the drop in domestic market share was much higher than during the period of economic slowdown (1999-2001). For example, in 19961998 the share of Polish exports in EU25 intra-exports increased by about 12 per cent, while in 1998-2001 was up more than 24 per cent. The domestic market

\footnotetext{
${ }^{16}$ when average GDP growth dynamics exceeded 7 percent per year.
} 
shares fell by $8 \%$ and 4 per cent, respectively. Although in 1996-1998 domestic demand was the main factor driving Poland's economic growth, the share of Polish products in the domestic market fell rapidly. It reflected the impact of extensive liberalisation of Polish market which bringing equal market access to all market participants - domestic and foreign, revealed lack of or very low competitiveness of Polish domestic oriented firms and the weakness of any real change in this regard in 1996-1998. The increased export orientation of Polish manufacturing at the end of the 1990s was accompanied by a diminishing drop in domestic market share. This suggests that some domestic oriented firms that had improved their competitiveness and new, competitive, entrants began to capture a part of the domestic market as well.

Summing up, high dynamics of GDP growth accompanied small progress in the increasing competitiveness of Polish manufacturing measured by changes in market share. The slowdown in the Polish economy was accompanied by an improvement in this position. Since a significantly smaller part of Polish production managed to win in the competitive fight with foreign rivals, on both the domestic and EU markets, the scope for integration of Polish manufacturing into the EU market in the first, as compared to the second, sub-period seems much lower. To confirm this hypothesis we turn to the analysis of factors that impact on the differentiation in scope of integration between two sub-periods.

Firms compete via price and quality. The difficulty in evaluating product quality in the economic sense of the word means that it is extremely difficult to use the price/quality relation as an indicator of ability to compete. Higher price may be the result of higher quality, but not lower competitiveness. Changes in prices may reflect changes in product quality and shifts among quality segments of a given product market. This is why, when evaluating changes in the ability of product industries to compete, one should base analysis on changes in relative labour productivity measured by relative unit labour costs rather than on relative prices. Given that this paper deploys a competitive rather than an economic growth approach to competitiveness, unit labour costs (ULC) would seem to be more relevant than value added per employee as a measure of labour productivity ${ }^{17}$.

Average ULC in a given period, both for Poland and the EU, is evaluated and

\footnotetext{
${ }^{17}$ Glikman and Lipowski (2005) analyzing changes in competitiveness of Polish export to Russia during period of slowdown of Russian economy (1997-2000) based on import market share and relative prices.

${ }^{18}$ Wziątek-Kubiak at al. (2004)
} 
Table 2. RULC and RUEV of Polish manufacturing in 1996-2001

\begin{tabular}{l|l|r|r|r|r|r|r}
\hline & & 1996 & 1997 & 1998 & 1999 & 2000 & 2001 \\
\hline \multirow{2}{*}{ RULC } & Level (weighted mean) & 0.77 & 0.79 & 0.81 & 0.79 & 0.75 & 0.77 \\
\cline { 2 - 8 } & median & 0.96 & 0.98 & 1.01 & 0.97 & 0.93 & 0.95 \\
\hline \multirow{2}{*}{ RUEV } & Level & 0.54 & 0.59 & 0.62 & 0.59 & 0.68 & 0.70 \\
\cline { 2 - 8 } & Differentiation & 59 & 61 & 61 & 55 & 114 & 72 \\
\hline
\end{tabular}

Source: own estimates based on sources as in Table 1.

compared for equivalent Polish and EU industries. ULC are derived by dividing the wages and social contributions of a given industry by its total sales. Since its labour force is relatively cheap and skilled and the level of capital per employee is low ${ }^{18}$, labour costs are widely recognised as a major element of Poland's competitive advantage. ULC indicate if changes in wages are compensated by changes in productivity. They are influenced not only by levels and changes in labour costs, but also by capital productivity, the learning costs phenomenon ${ }^{19}$, greater cumulative output and other factors. However, this measure is not free from some deficiencies, for example it is influenced by changes in unit intermediate (material, inputs and energy) costs and the rate of depreciation, where an increase results in a drop in ULC. Relative unit labour costs (RULC) are explored for each area of Polish manufacturing and compared to the EU average. Whenever RULC is above 1 (ULC in Poland higher than in the EU), the efficiency of the use of the labour force in Poland is lower than in the EU.

Table 2 illustrates that in the analysed period in terms of average (weighted with turnover) RULC Poland held a competitive advantage over the EU15. RULC kept worsening (by 7.4\%) during the period of high growth dynamics (1996-1998) and significantly improved (by 5.4\%) during the period of slowdown. The provisional estimations of data for 2002 and 2003 prove that relative labour productivity of Polish manufacturing continued to increase. However, in the years 1998-2001 the main factor contributing to a fall in RULC was a strong decrease in employment, occurring simultaneously to a stabilisation of wages and salaries ${ }^{20}$.

Changes in the market position of Polish manufacturing were linked to changes

\footnotetext{
${ }^{19}$ Fudenberg, Tirole (1980); Guber (1994)

${ }^{20}$ Within this period employment in the manufacturing industry fell by $18 \%$ ( $21 \%$ by 2002$)$, whereas in the years 1996-1998 it decreased by 3\%. Such a drop in recent years reveals not only the on-going restructuring of Polish manufacturing industry but also that the shallow reserves of productivity growth have become largely exhausted.
}

${ }^{21}$ Wziątek-Kubiak, Winek (2005) 
in relative labour productivity. Results of estimations using the multi-logit model ${ }^{21}$ show that changes in both market shares follow changes in RULC. However, the much stronger differentiation of level and changes in Polish manufacturing labour productivity as compared to the EU (standard deviation ranged from 0.45 to 2.5 ) indicate that some Polish industries are non-competitive.

As on the 3-digit level the data include sales values for industries taken as a whole rather than specific products. Comparisons of unit values are also affected by differences in the product mix and their changes. This is why the relative unit export value (RUEV) is introduced as a proxy for the quality position of Polish exports relative to the EU15 as compared to the EU15's internal exports. It is defined as the export euro value of a given industry divided by its physical weight (one kilogram). In the literature ${ }^{22}$ it is suggested that the unit export value is for many countries a good "overall" quality indicator, since it comprises many different aspects of product quality. Although it reflects changes in quality, shifts between product segments and other value enhancing features (service component, design and advertising) it is not free from some deficiencies ${ }^{23}$. RUEV indicates specifically in which quality segment of a given industry Polish-based producers operate, in comparison to their EU counterparts. A drop in RUEV signals a fall in prices and often reflects increasing competition by prices. It indicates that firms do not improve the quality of the product as much as their competitors did or shift to a higher quality segment of a given product market. It is possible they also shift to a lower priced segment of a given product market.

The differences in GDP per capita between Poland and the EU is reflected in a difference in structure of demand in favour of lower quality goods in Poland. However, the catch-up process (in terms of disposable income and productivity) taking place in Poland since the beginning of the transition has accelerated changes in the structure of demand in favour of higher quality. As Polish consumer demand for low quality goods diminishes in favour of higher quality ones, the potential of low quality producers to sell on the domestic and EU markets also diminishes. This means that those Polish producers that do not upgrade products and do not shift to the higher quality ones, although they are competitive and compete-out other

\footnotetext{
${ }^{22}$ Aiginger (1998)

${ }^{23}$ Changes in unit export values for a given product category may reflect both changes in product quality and changes in product bundle [Aw and Roberts 1986]. The more aggregated the product is the more serious the problem becomes. It may be different from unit prices since it represents a unit of weight rather than the price of any unit [Rosati 1998].
} 
(including EU) producers, may be locked into a "low-quality trap" (Dureck 2002), which would impact on their integration into the European Single Market in the long run.

One effect of the increase in relative labour productivity was that Polish manufacturing increased its competitive pressure on the EU market. However, the low average level of RUEV of Polish exports to the EU suggests that Polish products tend to meet demand from low and medium-income consumers. Improvement in RUEV also suggests its impact on the increase of Polish export in the EU market share. An upward shift in the quality of Polish manufacturing (RUEV of Polish manufacturing exports increased from 0.55 in 1996 to almost 0.7 in 2001) conceals a deep differentiation in the level of and changes in RUEV and RULC across industries, much higher than in the case of the EU.

\section{Diversification of Polish manufacturing industry in respect to changes in the ability to integrate into the European Single Market}

In the literature, changes in export market share tend to be explored as a measure of changes in the competitiveness of a given industry. Changes in domestic market share are commonly neglected. Poland's entry into the EU implies, however, that the domestic market is now part of the enlarged Single Market and should therefore be a part of our analysis. The question arises as to whether changes in both market shares would not be a more adequate measure of changes in the competitiveness and in the integration of Polish manufacturing than just changes in export market share.

In this section two steps in the analytical process are introduced. The focuses of the first step is changes in Polish exports in relation to EU market share (hereafter termed EU market share). Two parts of Polish industries are selected: those that increased their share of the EU25 market and those whose position deteriorated. The average RULC has been calculated for each part and both sub-periods (Table 3). The second step, focusing on changes in both domestic and EU market shares, extends the analysis. Four sub-parts are selected and the average RULC and RUEV for each sub-part is calculated.

Table 3 shows that in 1996-1998 both relative labour productivity and relative quality of industries for the first part were higher than for the second one. Differences in RULC between these parts increased in the analysed period from $1 \%$ to about 20\%. Although in 1996-1998 the RULC and RUEV increasing overall, the rise of RULC was significantly lower and RUEV higher in the 
Table 3. Changes in RULC and in RUEV in industries which improved and diminished shares in the EU market in 1996-2001

\begin{tabular}{c|c|c|c|c|c|c|c}
\hline & & \multicolumn{2}{|c|}{$\begin{array}{c}\text { Industries which } \\
\text { increased their share } \\
\text { on the EU market } \\
\text { (part I) }\end{array}$} & $\begin{array}{r}\text { Industries which } \\
\text { decreased their share } \\
\text { on the EU market } \\
\text { (part II) }\end{array}$ & $\begin{array}{r}\text { Average of Polish man- } \\
\text { ufacturing }\end{array}$ \\
\hline \multirow{2}{*}{ RUEV } & period & $\begin{array}{c}\text { average } \\
\text { level }\end{array}$ & $\begin{array}{c}\text { Changes } \\
\text { (in per cent) }\end{array}$ & $\begin{array}{c}\text { average } \\
\text { level }\end{array}$ & $\begin{array}{c}\text { Changes } \\
\text { (in per cent) }\end{array}$ & $\begin{array}{c}\text { average } \\
\text { level }\end{array}$ & $\begin{array}{c}\text { Changes } \\
\text { (in per cent) }\end{array}$ \\
\cline { 2 - 9 } & $1996-1998$ & 0.59 & 17.0 per cent & 0.50 & -5.6 per cent & 0.57 & 12.8 per cent \\
\hline \multirow{3}{*}{ RULC } & $1996-2001$ & 0.62 & 16.2 per cent & 0.59 & 0.4 per cent & 060 & 12.5 per cent \\
\cline { 2 - 9 } & $1996-1998$ & 0.99 & $6.1 \% / 74 / *$ & 1.24 & $13.9 \% / 16 /$ & 1.04 & 7.4 per cent \\
\cline { 2 - 9 } & $1998-2001$ & 0.96 & $-5.7 \% / 71 /$ & 1.0 & $-3.6 \% / 19 /$ & 1.0 & -5.2 per cent \\
\hline
\end{tabular}

*in brackets-the number of industries

Source: Comext, NewCronos, F01 databases, own calculations.

industries that strengthened their position on the EU market. The improvement in the RULC of industries that increased EU market share in the second sub-period was much stronger than industries in which EU market position deteriorated. Industries that strengthened their position on the EU market were characterised by higher relative levels of labour productivity and quality as compared to those industries which were competed out of the EU market. This leads to the conclusion that differences in trends in changes in EU market share reflect differences in level and changes in relative productivity.

From this, employing simultaneously two criteria of changes in the competitiveness of Polish manufacturing industries (i.e. changes in both domestic and EU markets shares) four sub-parts are selected (Table 4). Sub-part I (top) comprises those industries that increased their share of both domestic and EU25 intra-exports. In contrast with the above sub-part IV covers industries which in a given period lost their shares in both markets (sub-part four). In sub-parts II and III, industries that saw a divergence in trend changes on both markets are included. Sub-part II consists of industries that increased their share in the EU and simultaneously decreased their share of the domestic market. Sub-part III contains industries that increased their share of the domestic market, but simultaneously diminished their share of the EU market.

Table 4 shows that incorporating changes in domestic market share into the equation confirms there is differentiation of both parts of Polish manufacturing in 
Table 4. Characteristics of four sub-parts of Polish manufacturing

\begin{tabular}{|c|c|c|c|c|c|}
\hline & \multirow{3}{*}{ Period } & \multicolumn{2}{|c|}{$\begin{array}{l}\text { Industries whose share of the } \\
\text { EU market increased }\end{array}$} & \multicolumn{2}{|c|}{$\begin{array}{c}\text { Industries whose share of the } \\
\text { EU market increased }\end{array}$} \\
\hline & & $\begin{array}{c}\text { share of the } \\
\text { domestic market } \\
\text { increased } \\
\text { (I sub-part) }\end{array}$ & $\begin{array}{c}\text { share of the } \\
\text { domestic marke } \\
\text { diminished } \\
\text { (II sub-part) }\end{array}$ & $\begin{array}{c}\text { share of the } \\
\text { domestic market } \\
\text { increased } \\
\text { (III sub-part) }\end{array}$ & $\begin{array}{c}\text { share of the } \\
\text { domestic market } \\
\text { diminished } \\
\text { (IV sub-part) }\end{array}$ \\
\hline & & $\begin{array}{l}\text { Level (no of } \\
\text { industries) }\end{array}$ & $\begin{array}{l}\text { Level (no of } \\
\text { industries) }\end{array}$ & $\begin{array}{l}\text { Level (no of } \\
\text { industries) }\end{array}$ & $\begin{array}{c}\text { Level } \\
\text { (no of industries) }\end{array}$ \\
\hline \multirow{3}{*}{ RULC } & 1996-1998 & $\begin{array}{l}0.97 \\
(25)\end{array}$ & $\begin{array}{l}1.05 \\
(50)\end{array}$ & $\begin{array}{r}1.03 \\
(5)\end{array}$ & $\begin{array}{r}1.18 \\
(8)\end{array}$ \\
\hline & $1998-2001$ & $\begin{array}{c}0.90 \\
(40)\end{array}$ & $\begin{array}{l}1.14 \\
(32)\end{array}$ & $\begin{array}{r}1.03 \\
(6)\end{array}$ & $\begin{array}{l}1.34 \\
(10)\end{array}$ \\
\hline & $1996-2001$ & $\begin{array}{l}0.91 \\
(31)\end{array}$ & $\begin{array}{l}1.07 \\
(44)\end{array}$ & $\begin{array}{c}1.00 \\
(1)\end{array}$ & $\begin{array}{l}1.27 \\
(12)\end{array}$ \\
\hline \multirow{3}{*}{ RUEV } & 1996-1998 & 0.60 & 0.55 & 0.68 & 0.41 \\
\hline & $1998-2001$ & 0.65 & 0.58 & 0.63 & 0.71 \\
\hline & $1996-2001$ & 0.65 & 0.60 & 0.78 & 0.53 \\
\hline
\end{tabular}

Source. Comext, NewCronos, F01 databases, own calculations

terms of level of and changes in RULC. It is worth underlining that the relative labour productivity of those industries that saw diminished domestic market shares was lower than the industries whose domestic market share strengthened. A similar rule can be noted in the case of those industries that differ in terms of trend changes in EU market shares. In other words, changes in both market shares matter for an evaluation of changes in the competitiveness and integration of Polish manufacturing into the Single Market. This is all the more so given that the only sub-part that improved labour productivity was industries in the first sub-part. RULC of export-oriented industries (sub-part II) increased.

Comparison of the RULC of sub-part I with that of sub-part IV confirms our hypothesis that an increase in both market shares reflects improvement in competitiveness and progress in integration. In the analysed period a drop in both market shares reflected diminishing ability to integrate. Differences in RULC levels between these two sub-parts increased from 22 per cent to 50 per cent.

The introduced measures of changes in the ability to compete reflect the polarisation of Polish manufacturing in terms of ability to integrate. Furthermore, in terms of RULC both the first and fourth sub-parts were the most homogenous (the standard deviation of RULC was the lowest and diminishing). Surprisingly, the most differentiated with respect to level of and changes in RULC was sub-part 
II: export-oriented industries. The increasing differentiation of this last one and the third sub-part indicates that in the nearest future some industries that belong to these sub-parts will shift to other sub-parts. It is impossible to detect this process by focusing on changes in export market share exclusively. Overall, changes in both domestic and EU market share is a better measure of changes in the ability to compete and to integrate into the Single Market than a measure of changes in export market share.

The most significant progress in terms of labour productivity was typical for industries that increased both domestic and EU market shares and whose RULC was the lowest at the very beginning (in 1996). Higher labour productivity at the very start was more conducive to its later improvement.

\section{The winners and the losers of Polish manufacturing}

Improvement in the labour productivity and quality of goods of Polish manufacturing has tended to result in a shifting of industries among four sub-parts. This in turn yielded changes in average relative labour productivity (RULC) of selected sub-parts in 1998-2001 as compared to 1996-1998 (Table 4). An upward shift of industries suggests increases in the ability to compete and integrate into the Single Market. The opposite was seen in the case of downward shifts.

In 1998-2001 as compared to 1996-1998 almost half of the total number of industries shifted among the four sub-parts. The outcomes of each sub-part of Polish manufacturing is very dependent on the analytical timeframe deployed. The biggest outflow came from industries whose changes in market share diverged. Only five industries radically changed market position (from the top to the bottom sub-part or in the opposite direction). Surprisingly, during the slowdown of Polish economy most industries that shifted between the four sub-parts also improved their position on the domestic market.

In 1998-2001, compared to 1996-1998, almost half of those industries shifting between the four parts moved into the most competitive sub-part (Graph 1). Their improvement in RULC confirms its crucial role in strengthening domestic market position. Simultaneously, in both sub-periods most industries from sub-part II and sub-part I stayed within their respective sub-parts. In 1998-2001, relatively few (8) industries changed position downwards in both markets. However, in the case of only two of them market position deteriorated in both periods. The most stable was sub-parts I, and the least stable was the lowest sub-part. The homogeneity of industries in the best and worst sub-parts in terms of RULC confirms that 
Graph 1. Number of industries in each sub-part in 1996-1998 and shifts to other sub-parts in $1998-2001$

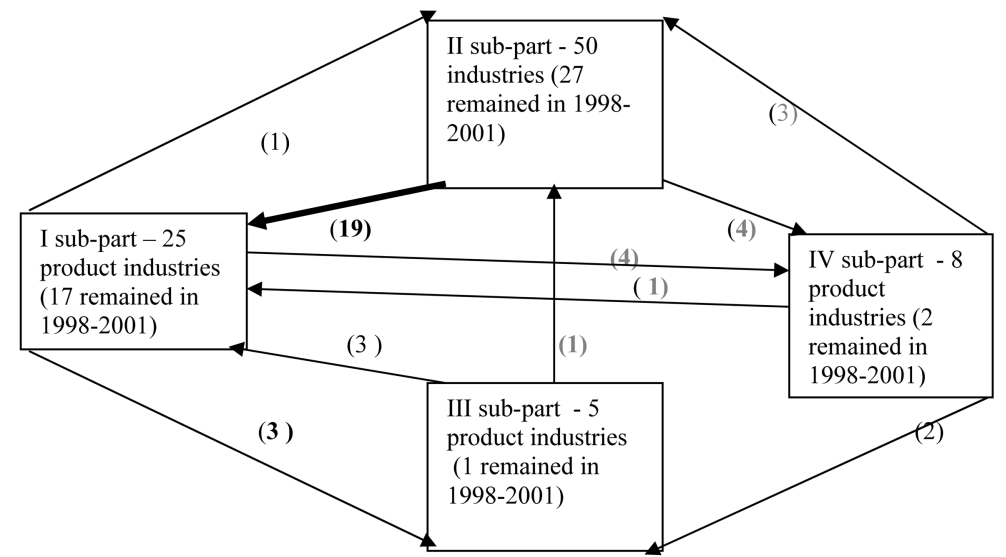

in blocks, in brackets-number of industries that did not shift to other sub-parts in both subperiods.

improvement/deterioration on both market shares is a relevant indicator of changes in competitiveness.

Based on the criterion of direction shift of industries between the four selected sub-parts of Polish manufacturing in 1998-2001 compared to 1996-1998 and considering level of and changes in RULC, three clusters of Polish manufacturing were selected: the losers, the winners and those industries that remained "in between". The losers are those industries that shifted to or stayed within the lowest sub-part in both sub-periods. Their RULC was either very high or/and deteriorated. Those industries that improved their position on both markets and whose RULC stayed low or improved in 1998-2001 were classified as winners. Remaining industries are termed as "in between".

The winner cluster contains the biggest number of industries (67). In the analysed period they were the most dynamic sub-part of Polish manufacturing. Their export dynamics exceeded the average dynamics of Polish manufacturing exports and EU25 intra-exports. The domestic market position of most of them strengthened (Table 5). Their increasing export orientation was based on improvement in the ability to compete and integrate into the Single Market. However, the level and changes in RULC of these industries was differentiated and differentiating. An interesting rule emerges here. The very low (in 1996-1998) RULC of seven industries that strengthened their market positions in both subperiods deteriorated a little in 1998-2001. The higher RULC of those industries that 
Table 5. Characteristic of the winners, losers and "in between" industries

\begin{tabular}{|c|c|c|c|c|c|c|c|c|c|}
\hline \multirow[b]{2}{*}{ Cluster } & \multirow[b]{2}{*}{ Period } & \multicolumn{2}{|c|}{$\begin{array}{l}\text { changes in } \\
\text { share (in \%) }\end{array}$} & \multicolumn{2}{|c|}{ RULC } & \multicolumn{2}{|c|}{ RUEV } & \multicolumn{2}{|c|}{ RUI } \\
\hline & & EU-25 & Domestic & $\begin{array}{c}\text { average } \\
\text { level }\end{array}$ & $\begin{array}{c}\text { changes } \\
\text { (in percent) }\end{array}$ & $\begin{array}{c}\text { average } \\
\text { level }\end{array}$ & $\begin{array}{c}\text { changes } \\
\text { (in percent) }\end{array}$ & $\begin{array}{c}\text { average } \\
\text { level }\end{array}$ & $\begin{array}{c}\text { changes } \\
\text { (in per- } \\
\text { cent) }\end{array}$ \\
\hline \multirow{3}{*}{ winners } & 1996-1998 & 35 & -11 & 0.98 & 6.6 & 0.59 & 15 & 1.9 & 39.0 \\
\hline & $1998-2001$ & 74 & -5 & 0.98 & -4.9 & 0.64 & 17 & 1.6 & -18.6 \\
\hline & 1996-2001 & 138 & -14 & 0.98 & 1.0 & 0.61 & 81 & 1.7 & -1.6 \\
\hline \multirow{3}{*}{ losers } & 1996-1998 & -6 & -27 & 1.25 & 24.2 & 0.52 & 13 & 1.4 & -1.9 \\
\hline & $1998-2001$ & -24 & -22 & 1.33 & 6.0 & 0.56 & 13 & 1.3 & -33.2 \\
\hline & 1996-2001 & -30 & -40 & 1.29 & 30.4 & 0.54 & -9 & 1.4 & -26.9 \\
\hline \multirow[t]{2}{*}{ in } & 1996-1998 & -1 & 6 & 1.22 & 3.2 & 0.60 & 8 & 1.6 & 77.6 \\
\hline & $1998-2001$ & 21 & -13 & 1.23 & -1.9 & 0.63 & 30 & 1.7 & -2.5 \\
\hline between & 1996-2001 & 6 & -8 & 1.23 & -0.2 & 0.62 & 25 & 1.6 & 63.8 \\
\hline
\end{tabular}

Source. Comext, NewCronos, F01 databases, own calculations

shifted to the top sub-part diminished. In effect, in 1998-2001 in terms of RULC the highest competitive advantage was possessed by industries that stayed within the top sub-part or shifted into this sub-part.

The winner cluster was also characterised by the highest RUI (relative unit investment rate $^{24}$ ), although its level was differentiated among industries. The changes in 1996-2001 do not reflect the changes that took place in both subperiods. In 1998-2001, the RUI deteriorated in the case of industries that stayed within sub-parts II and I. It increased a little in the case of industries that shifted into the top sub-part. The example of the winners did not confirm the results of the multi-logit, which posits that changes in market share do not follow changes in investment rate ${ }^{25}$.

In terms of relative quality of products, the winners cluster was highly differentiated. However, it contained the largest part of Polish industries operating in the high quality segment of the EU market.

Summing up, an upward shift of industries among the four sub-parts and holding position within the first sub-part followed a low and falling RULC and an increase in RUI. Deterioration of position, i.e., a shift from the top to other sub-parts, was followed by high and deteriorating RULC, RUI and RUEV.

The losers cluster contains 17 Polish manufacturing industries. During both sub-

\footnotetext{
${ }^{24}$ Relation between investment in tangible goods and sales.

${ }^{25}$ Wziatek-Kubiak, Winek (2005)
} 
periods they were pushed out of the Polish market. Their share of EU25 intraexports either diminished in both sub-periods or increased slightly only in 19961998. They were characterised by the highest RULC, which increased considerably in both sub-periods. Low relative investment rate accompanied a very strong drop during slowdowns in the Polish economy. The RUEV was the lowest and in many industries it deteriorated further. They competed at a low quality level, mainly via prices. The increase in RULC that accompanied the drop in RUEV indicates weak ability to adjust costs to declining quality of products.

The "in-between" cluster contained 12 industries. It was the most differentiated cluster of Polish manufacturing. However, performance of a few industries in this cluster impacted on the average indicators for this cluster. Firstly, this cluster was characterised by differentiation in terms of trends in changes of share of domestic and EU markets in each of two sub-periods. Some increased their share of the EU25 market, while others did so on the domestic market. Although some of them improved positions on the EU market, their export dynamics were much lower than the winners. Secondly, their RULC was similar to the losers' cluster. However, in contrast to the latter, the RULC of the analysed industries diminished either in both or in the second sub-period. The lower increase in RULC than in the losers' case in 1996-2001 was the effect of an improvement in labour productivity during slowdowns in the Polish economy. They adjusted better to the less favourable Polish macroeconomic condition than did the losers. Thirdly, RUI level was a little higher than for the losers and was similar to the winners level. It increased in the second sub-period (in the case of the losers deteriorating) somewhat. Last but not least the RUEV was very highly differentiated and on average increased a little. It diminished in the case of industries where the RUEV was quite high, while in the case of other industries of this cluster improved.

As compared to the losers, "in between" industries differed in terms of higher export dynamics to the EU, which resulted in an improvement in EU market position. This reflected the increase in relative labour productivity and investment rate. The increasing export orientation came at the cost of weaker domestic market deliveries. The term "fighting" industries can be their distinguishing feature.

In terms of all the deployed measures there were quite large differences between the winners and the two other segments of Polish manufacturing. In both subperiods the RULC of the winners was the lowest. During slowdowns in Polish economic growth the differences between the three clusters even increased. In contrast to the losers' cluster, the RULC of the winners and "in between" clusters 
improved. In effect, in terms of level of RULC, the differences between the winners and the losers increased from 27 per cent to almost 40 per cent, while between the winners and the "in between" industries from 24 per cent to 33 per cent. Undoubtedly, in terms of RULC the winners had advantages over both clusters and exhibited a better ability to adjust to changes in macro conditions, a higher ability to compete on both the domestic and EU markets and to integrate into the Single Market. Improvement in market position of the winners during slowdowns in economic growth, as well as improvements in RULC, proves their high ability to integrate into the enlarged European Market.

\section{Conclusions}

Polish manufacturing industries are clearly differentiated in terms of their ability to integrate into the Single Market. One sees a polarisation of Polish manufacturing industries taking place in the analysed periods. Those industries that improved their relative labour productivity, quality of goods and rate of investment strengthened their positions on the enlarged EU market. Those industries whose relative labour productivity and quality of products deteriorated either weakened their market position or were competed out of the market. Most Polish manufacturing industries increased their ability to integrate into the Single Market. Despite foreign trade liberalisation, the winners improved their relative labour productivity and quality of products. Most industries that produced high quality products belonged to the winners cluster. The opposite was the case for a few industries (losers) whose market position deteriorated. In all respects the differences between the losers and the winners increased considerably. However, progress in integration within the winners cluster was differentiated. If some of them fail to improve their relative labour productivity and raise their product quality they will be competed out of the enlarged European market in the near future.

Analysis shows that, firstly, differentiation in changes in both domestic and EU market shares has accompanied differentiation in level and changes in relative labour productivity and product quality. Changes in both domestic and EU market shares better reflects changes in the ability to integrate into the Single Market than incorporating only changes in export market shares.

Received 15 May 2005, Accepted 31 July 2006 


\section{References}

Aiginger, K. (1998), Unit Value to Signal the Quantity Position of CEECs, in The Competitiveness of Transition Economies, OECD, Paris, pp. 93-121.

Aiginger, K. (2001), Measuring the Intensity of Quality Competition in Industries, WIFO - Quarterly No. 1.

Aw, B.Y. and Roberts, M.J. (1986), "Measuring quality change in quota-constrained imports market. The case of US footwear", Journal of International Economics, 21, 45-60

Casson, M. (1999), International Competitiveness, Routledge, London, pp. I-XV.

Dlugosh and al. (1996), Do current account deficits and surpluses matter? Edward Elgar, Cheltenham, UK, Brokkfield, US

Dulleck, U. (2002), Trade and Transition - is there a low quality trap? WIFO, mimeo, 1-16.

Eichengreen, B., Parry, Ch. W., Caldwell, P. (1988), International Competition in the Products of U.S. Basic Industries, in The United States in the World Economy, Edited by M. Feldstein, The University of Chicago Press, Chicago

Feenstra, R. C. (1989), Trade Policies for International Competitiveness, Edited by Feenstra, R. C. and al., The University of Chicago Press, Chicago, pp. 70-96

Frischtak, C. (1999), Manufacturing, Competitiveness: Concept, Measurement Policies, in Competition and the World Economy UNIDO, Edited by Sercovich, F., and al. Edward Elgar, Cheltenham

Fudenberg, D. Tirole, J. (1980), Learning by doing and market performance Bell Journal of Economics" vol.14, 522-30

Glikman, P., Lipowski, A. (2005), Konkurencyjność a rywalizacja na przykładzie eksportu polskiego do Rosji w latach 1997-2000, Key Text, Warszawa

Gomory, R.E., Baumol, W. (2000), Global Trade and Conflicting National Interests, The MIT Press Cambridge, Massachusetts, London, England.

Grossman, G.M., Helpman, E. (1991a), Quality ladder in the theory of growth, Review of Economic Studies, 59, 43-61.

Grossman, G.M., Helpman, E. (1991b), Quality ladders and product cycles, Quarterly Journal of Economics, 425, 557-586

Gruber, H. (1994), Learning and Strategic Product Innovation, North-Holland, Amsterdam

Meeusen, W., Rayp, G. (2000), Patents and Trademarks as Indication of International Competitiveness, in Competitiveness and Value of Intangible Assets, Edited by Buigues, P., Jacquemin, A., Marchipont, J. F., Edwards Elgar, Cheltenham, pp. 268285.

Martin, S., J. (2003) Globalisation and the natufal limits of competition in The International Handbook of Competition, Edited by Neumann, M., Weigand,Edward Elgar, Cheltenham, UK, pp. 16-49

Misala, J. (1995), Competitiveness of Polish Products on market of the European Union Member Countries (in:) Poland: Towards increased Competitiveness and 
Development, IRiSS, Working Papers no 6, Warszawa.

OECD, (1998), The Competitiveness of Transition Economies, Paris

Porter, M. E. (1990), The Competitive Advantage of Nations, The Macmillan Press Ltd. Houndmills.

Raynauld, A., Vidal, J. P. (1998), Labour Standards and International Competitiveness. A Comparative Analysis of Developing and Industrialized Countries, Edward Edgar, Cheltenham.

Rosati, D. (1998), Emerging Trade Patterns of Transition Countries: Some Observations from the Analysis of 'Unit Values', MOCT-MOST, 8. Kluver Academic Publisher, pp. 51-66

Tumpel-Gugerell, G. (2003), Introduction in Economic Convergence and Divergence in Europe. Growth and Regional Development in an Enlarged European Union, Edited by Tumpel-Gugerell, G., Mooslechner, P., Edward Elgar, Cheltenham, UK

Wysokińska, Z. (1995), Dynamiczne współzależności wymiany handlowej krajów Europy Środkowo-Wschodniej $w$ świetle teorii integracji $i$ wymiany międzynarodowej, Uniwersytet Łódzki, Łódź

Wziątek-Kubiak, A., Lipowski, A. (2000), Zmiany konkurencyjnoœci produkcji przemysłowej w latach 1994-1998 in Struktura gospodarki transformującej się. Polska 1990-1999 (projekcja do roku 2010), Edited by A.Lipowski, Ziggurat, Warszawa, pp. 111-149

Wziątek-Kubiak, A. (2000), Dostosowanie się eksportu Polski, Czech i Węgier do zmian importu Unii Europejskiej in Unia Europejska wobec procesów integracyjnych. Wyzwania dla Polski, WSHiFM, Warszawa.

Wziątek-Kubiak, A. (2004), Changes in the Competitive Pressure of the Czech Rep., Hungary and Poland in the Enlarged EU Market, Mimeo, Warsaw

Wziatek-Kubiak, at al. (2004a) Differences in productivity and its determinants among firms from the Czech Republic, Hungary, Poland and Germany. The case of the cosmetics industry, CASE, Studies and Analyses, No. 284

Wziatek-Kubiak, A.,Winek, D. (2005), Changes in Competitive Advantage of Transition Economies. Measurement and Factors in Structural Change and Exchange Rate Dynamics in the Context of the EU Eastern Enlargement, Edited by Welfens, P., Wziątek-Kubiak, A. Singer-Verlag, Belin, Heidelberg 